TONI BIELIĆ, Ph.D.

E-mail: toni.bielic@pfst.hr

University of Split, Faculty of Maritime Studies

Zrinsko-Frankopanska 38, HR-21000 Split, Croatia

ROBERT MOHOVIĆ, Ph.D.

E-mail: mohovic@pfri.hr

RENATO IVČE, Ph.D.

E-mail: ivce@pfri.hr

University of Rijeka, Faculty of Maritime Studies

Studentska 2, HR-51000 Rijeka, Croatia
Traffic Management

Review

Accepted: May 14, 2010

Approved: Dec. 21, 2010

\title{
SOCIOTECHNICAL MODEL OF SHIP ORGANIZATION EFFECTIVENESS
}

\begin{abstract}
This article investigates the possibility of optimizing the organization of a ship as a highly complex technical system. In this sense, the existing relationship between technology and the human as a user is considered. Using the sociotechnical approach the aim is to identify the weaknesses in the existing technological and organizational ship's system. Based on research conducted on the navigation simulator, socio-technical components that affect the safety of navigation have been observed. By subsequent comparative analyses of the implementation of technical solutions in accordance with the human requirements certain solutions are proposed and conclusions made.
\end{abstract}

\section{KEY WORDS}

socio-technical model, ship organization, safety, effectiveness, technology indulgence, control systems, automation

\section{INTRODUCTION}

The crew of a ship is gradually but continually put in the position of dependence by the advantages of advanced technology solutions at management level. The knowledge and the feeling that technical systems may fail are increasingly suppressed. Uncritical acceptance of information provided by such systems in terms of automation, information technology and selfcontrol of the working conditions leads to indulgence in technical and technological solutions. At a time when uncritical submission to and compliance with technology lead to dependence on technology, which means that our working knowledge and skills are no longer fundamental factors in making and implementing decisions, then we speak about the phenomenon of technology complacency and technology as a form of uncritical indulgence in technological solutions. This is also an asynchrony which leads to the fall of orga- nizational effectiveness in terms of human resources and safety of navigation.

An example of such a phenomenon in maritime accidents was the Titanic whose master, due to the general belief in the ship's inability to sink, came himself under the influence of the superiority of the vessel and, among other things for this reason he suppressed his acquired knowledge, experience and caution.

That such attitudes are still present and even more dangerous due to possible impacts on the environment has been confirmed by the case of the collision of the passenger ship Norwegian Dream and the container ship Ever Decent. Until the last moment, the officer of the Norwegian Dream relied on the radar information that was not properly selected considering the conditions. The same element of wrong interpretation of the radar image and reliance on ARPA (Automatic Radar Plotting Aid) has been noted in the event of a collision of cargo ships Pyotr Vasev and Admiral Nakhimov, where the master of Vasev himself came under the influence of the so-called "radar hypnosis" and neglected all other sources of information, including his active knowledge and experience of visual observation.

Thus, uncritical acceptance of technology as an observed form of dangerous conduct expressed through the phenomenon of complacency is a current sociotechnical process that accompanies the constant tendency towards automation of technological processes applied to the ship's control.

\section{SOCIO-TECHNICAL ANALYSIS OF THE IMPACT OF TECHNOLOGY AND WORK ENVIRONMENT ON THE PASSIVIZATION OF ACTIVE KNOWLEDGE}

In scientific literature the notion of socio-technics is commonly encountered. In addition, the terms such 
as socio-technical theory, socio-technical systems and theories of socio-technical systems commonly appear. But regardless of the term the basic purpose of the concept of socio-technics is proposing numerous and different ways to achieve optimal unity of human and technical resources. In this sense the term is often used to simplify and appropriately describe any type of organization consisting of people and technology. Socio-technical theory suggests that the human factor and social institutions form an integrated system, and that the attainment of organizational goals is not achieved by optimizing the technical elements, but by the joint optimization of social and technical resources (Trist \& Bamforth, 1951:39) ${ }^{1}$. As the ship organization is composed of people in close relation with the ship's technical systems and as interactivity of human and technical system is the basis of navigation safety, the notion of socio-technics can be applied in the full sense in the analysis of organizational and work processes. The socio-technical theory pays special attention to the internal control of organization and leadership at the level of "group" and refers to "responsible autonomy" of the team (ibid.). The key to "responsible autonomy" is in the organizational structure which basically should consist of small groups or teams responsible for their own internal organization and control with the primary task of establishing relationships with other groups, which is the explicit responsibility of group leaders (Rice, 1958: 246$)^{2}$. This principle, among other things, describes the strategy of removing the traditional hierarchical management which is still a burden to modern ship's organizations. Given the complexity of the ship as a technical system, only small groups of independent specialists - teams, can achieve effective interactivity between the managerial elements of ship's organization and technology that the ship has at its disposal. Accordingly, the sociotechnical approach seeks to achieve optimal interrelation between social and technical aspects within the organization and is based on two basic principles:

- Interaction of human and technical factors which, depending on the degree of compliance, create conditions for efficient or inefficient organization. This interaction can be linear as "cause-effect" one (which is an ordinary anticipated relationship) and partly non-linear, complex and thus can take a form of unpredictable relationships (good or bad, but always unexpected). Whether predictable or not, both interactive relationships occur when sociotechnical elements are put into operation.

- Consequently, the second principle is that optimization of each element individually (human or technical), independently of one another, tends to increase not only the possibility of unpredictable and unusual relationships, but rather such relationships lead to a drop in the efficiency of organizational system as a whole.
Applying the principles of socio-technical systems to the modern ship's organizational structure we come to the following facts:

According to the first principle the crew should be in compliance with the technical and technological aspects of the ship managed. However, this is often not the case due to the lack of usage standards applied to the equipment used for similar purposes, regardless of whether this refers to a part of the navigational, propulsion or other ship's technical subsystem. The dominant share of human error in maritime accidents (75-96\%) is basically not only the result of operator's error. Many of the mistakes that were made and that led to accidents arose from non-compliance of the ship's technology and the ship's crew members as users.

Non-standardized and, thus, often poorly designed equipment is cited as a causal factor in $1 / 3$ of the major maritime accidents (Wagenaar, 1987:587) ${ }^{3}$. From the standpoint of the first socio-technical principle the improvement of the safety and effectiveness of conducting a vessel as well as better usability from the viewpoint of equipment handling are not the primary targets. The primary goal is the systematic integration of four basic elements that in correlation form the human-ship relationship (Schuffel, 1981:7) ${ }^{4}$. These elements are:

- program (processes, rules, regulations);

- program holders (process dynamics, control systems, indicators);

- work environment (work climate, vibrations, noise);

- human labour functions (motivation, stress, skills).

Based on these four elements the following systems and relationships should be formed and known in advance:

- control systems,

- human-machine relationship.

Proper implementation of these systems and relationships can be achieved by effective organization of the ship by the first socio-technical principle. Looking at the organizational structure of the ship from the aspect of the second principle the mismatch in the co-evolution of human and technical elements is also visible. Namely, the element of the ship's technical development is strongly emphasized, which simultaneously is not an integral part of developing maritime organization in terms of human resources. The relationship between human and technical system has historical continuity with the transfer of work load from human onto the machine. This attitude is illustrated by Döring: "Man has the ability to predict or cognitive capabilities that allow him to see what he wants or expects to see, while the machine cannot have these features." Or "Man has the ability to foresee or cognitive abilities enabling him to see what he wants or expects to see whereas machine cannot have these abilities". "Man can recognize and use the relevant information 
from a multitude of details or examples in the real world with the aim of simplifying complex situations, while the machine has limited perceptual constant". (Döring, 1976:12) ${ }^{5}$ Accordingly, a clear distinction should be made of the automation of the processes which by their nature can help and support humans from those processes which passivize and reduce human concentration and efficiency in priority decisionmaking and selective acting. Given the marked development of technology that seeks to substitute the current human activity this leads to passivization of the traditional seafarers' knowledge as certain devices have taken over certain components of seafarers' active knowledge and skills. Because of the disparity in the dynamics of human and technical resources the ship's organization shows a certain inefficiency according to the second socio-technical principle which is reflected on the safety of exploitation of the ship as a technical system. Previous socio-technical considerations of ship's organizational-technological problems can be summarized as a schematic diagram of the socio-technical strategy (STS), which can be the basis for the formation of the system of parallel development of technical and social resources (Figure 1).

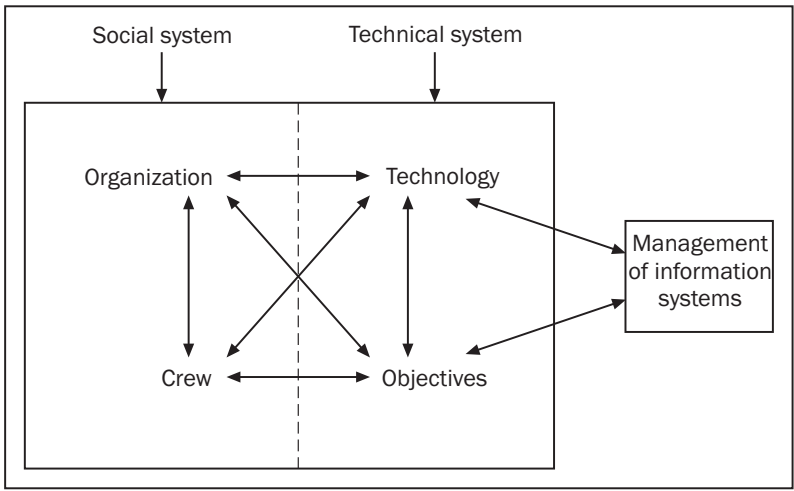

Figure 1 - Schematic model of socio-technical principles

Source: According to MIS Problems and Failures:

A Socio-technical Perspective. Bostrom, R. P., Heinen, J. S., MIS Quarterly, Vol. 1 Issue 3, September $1977^{6}$

Figure 1 shows the connection between social and technical systems which leads to better usability in the maritime industry. Furthermore, through the shown schematic model we can emphasize efficiency, effectiveness and satisfaction of users performing tasks with the system in a defined context of the socio-technical principles. This aspect is illustrated by Rasmussen (2005: 3): "Masters and crew want a ship that is easy to operate, comfortable and also safe, in the broadest sense of the word, and certainly with respect to the work environment." Earthy (2005: 2) defined usability through human-centred design which entails following socio-technical activities and principles:

"Understanding and specifying the context of use; Specifying the user and organizational requirements;
Producing design solutions; The active involvement of users and a clear understanding of user and task requirements; An appropriate allocation of function between users and technology; Iteration of design solutions."

Starting from these principles, ships as socio-technical systems have to be organized in such a manner that risks arising from mismatch between seafarers, their ship, its systems and operational procedures are mitigated.

\section{INVESTIGATION OF THE PHENOMENON OF SOCIO-TECHNICAL MISMATCH AND TECHNOLOGY INDULGENCE}

In order to prove the actual presence of the phenomenon of socio-technical mismatch and technology indulgence onboard modern ships, the following investigation was carried out on the navigation subsystem simulator.

The phenomenon of the impact of technology on passivization of active knowledge and skills from the aspect of navigation can be studied on modern navigation subsystems simulator that allow the simulation of real conditions of navigation and watch-keeping on the bridge. Such a possibility was realized in the North Control navigation subsystem simulator at the Faculty of Maritime Studies in Split.

With the visualization of the movement of the ship in a constant range of $220^{\circ}$ the simulator includes realistic elements of the navigating bridge modern equipment which includes two ARPA navigation radars, GPS (Global Positioning System), electronic chart, Doppler speed log and echo sounder, engine telegraph and engine condition indicators, the internal and external communication instruments, GMDSS (Global Maritime Distress Safety System) and VHF (Very High Frequency) equipment as well as steering gear with the corresponding elements of automatic steering and rudder deflection controls. In the simulator there is a chart table with the traditional nautical charts, and all the supporting equipment for navigation and passage planning. In addition to these essential elements the simulator includes other additional devices for determining wind speed and direction, monitoring rate of turn, etc.

The study of the phenomenon mentioned in the simulated sailing conditions aims at comparing the ratio of knowledge and skills in determining the ship's position and the application of automation positioning systems. The investigation was carried out in the field of determination of the position and conduct of navigation using terrestrial method of radar positioning as elements of active application of knowledge and skills, as well as the use of GPS and electronic charts and automated positioning devices that potentially passivize the skills mentioned. 
The study was conducted on 28 professional seafarers divided into seven groups of four. Each group represented a separate crew whose members had never met previously and that was expected to carry out the same task of simulated voyage as all the other groups. Within each group the seafarers were selected according to the positions they hold in real life, i.e. the master, first, second and third officers. A helmsman was then assigned to each group, who was supposed to carry out only the duty of the helmsman and as such was not the subject of investigation. The master was free to coordinate the first, second and third officers according to his assessment of the situation and personal experience. Terms of simulation were as follows:

Bulk cargo ship of $60,000 \mathrm{dwt}$ with a draft of $10 \mathrm{~m}$ and a length overall of $210 \mathrm{~m}$ was anchored at $2.5 \mathrm{M}$ northeast of the French port of Boulogne. The seafarers were given order by the company to leave the anchorage according to the traffic separation scheme for the English Channel, join the scheme and proceed to the North-West towards the Dutch port of Rotterdam. Navigation conditions were good with a visibility of $10 \mathrm{M}$ and sea state 3 . The ship was supposed to leave the anchorage at 14:00 hours local time during daylight. All navigation aids on the bridge were prepared including radars. Engine room was given the order "Stand-by engine room".

The investigation began with the first group on March 16, 2008 at 10:00 hours. While weighing anchor the master requested from the second officer to check the position and plot it on the nautical chart. The second officer first visually checked the position on the electronic chart, and then took the coordinates from the GPS device, and plotted them on the chart. The master tacitly accepted such an act and on the basis of insight into the position on the chart he ordered the course of leaving the anchorage. Some twenty minutes after leaving the anchorage and entering the traffic separation scheme the master was relieved by the first officer who also continued with plotting position on the chart based on data obtained from the GPS device. Plotting position on the chart was formal, while in reality the first officer during the voyage oriented on the basis of electronic chart and radar image which was used to determine the true and relative motion of nearby ships. At 10:30 hours the investigation was discontinued.

At 11:00 hours, after getting acquainted with the navigation equipment the second group began work in the same conditions as the previous group. When asked by the master about the position of the ship, the second officer used the GPS device as the reference data on position. The estimated point of the ship's turn onto the new course was stored as WP (waypoint) in the GPS device and electronic chart. Also, the movement of the ship towards the waypoint was visually monitored on the electronic chart and radar without plotting position on the nautical chart. On arrival at the point of ship's turn the master ordered the turn onto the new course after which the voyage continued in the traffic separation scheme to the port of destination. All the time the nautical chart was formally used for the determination of the course fixed on the basis of data from the electronic chart and GPS device. At 23:40 hours the simulation was completed.

At 12:10 the third group, after getting acquainted with the instruments of the bridge, began setting sail. The master requested the second officers to check the position. He specifically requested radar positioning and comparing the position obtained with the GPS position. After the comparison which showed minimal deviation both in the case of radar and the GPS position the master demanded from the second officer determination of position during setting sail and joining the traffic separation scheme only by radar positioning and the use of nautical charts. After turning onto the new course and proceeding towards the port of destination the position was determined by simultaneous use of radar and GPS, so the movement of the ship and its position on the nautical chart was compared with the position and movement of the ship on the electronic chart. At 12:45 hours the simulation was terminated.

After completion of practical preparations the fourth group started the manoeuvre of leaving the anchorage at 13:05. Previously, the master requested plotting the point of turn and joining the traffic separation scheme on the nautical chart as well as storing coordinates into the GPS device and electronic chart. The master took over the role of general control and issuing orders. After storing the coordinates into the GPS device and electronic chart leaving anchorage began on the basis of the position obtained from the GPS device. Until reaching the point of turning and entering the traffic separation scheme the position was checked by controlling the movements on the electronic chart and the GPS device which continued after the turn onto the course towards the port of Rotterdam. The simulation ended at 13:40 hours.

The fifth group began simulation on March 17, 2008 at 09:30 a.m. The master ordered the point of turn for entry into the traffic separation scheme on the nautical chart and requested from the second officer the storing of the coordinates into the GPS device, as reference points for altering course. Departure coordinates of setting sail were obtained from the GPS, and navigation towards the traffic separation scheme was followed on the electronic chart. During joining the traffic separation scheme and turning onto the course towards the port of Rotterdam the position was determined by the GPS device. Nautical chart was used only for formal plotting the departing position and that of turning onto the course towards the port of destination by the GPS coordinates. Navigation on the course to- 
wards the port of Rotterdam was controlled using the electronic chart and the GPS device. The simulation was completed at 22:20 hours.

The sixth group, after initial familiarization with the instruments, began sailing at 11:15 hours on the same day as the previous group. Although the second officer wanted to fix the position with the GPS device the master demanded radar position with two bearings. After the position was plotted on the chart the master requested plotting of the planned position of the ship's turn onto the new course in the traffic separation scheme on the starboard radar. In the course of navigation the second officer checked the position by radar and plotted it on the chart, so the master corrected the ship's course using this information. The master occasionally compared the course of the ship with the electronic chart, but he conducted the ship on the basis of radar positioning. After joining the traffic separation scheme and turning onto the course towards the port of Rotterdam the position was checked by parallel use of radar positioning and GPS coordinates. At 12:00 hours the simulation was completed.

At 12:30 the seventh group began with heaving the anchor. During this time the position was obtained from the GPS device, and the coordinates were plotted on the nautical chart. The position of the ship's turn in the traffic separation scheme was also stored into the GPS device as a reference point. On the nautical chart only two positions were plotted and they were both obtained from the GPS device. Joining the traffic separation scheme and turn onto the new course were followed on the electronic chart. On the nautical chart the GPS position was plotted as the position from which the course within the traffic separation scheme towards the port of Rotterdam was plotted. In the subsequent part of the simulation navigation was conducted with position checking exclusively by automatic, i.e. GPS positioning and visual checking of the electronic chart. In the course of navigation on the new course the position was plotted every 15 minutes on the nautical chart on the basis of GPS coordinates.

\section{Investigation results}

Looking at the work and actions of respondents in terms of influence of technology on passivization of knowledge and skills, and uncritical adoption of automatically obtained information on the ship's position, the following has been noted:

The first, second, fourth, fifth and seventh group of respondents chose the GPS position as a reliable and accurate position of the ship, and during setting sail and navigation they also used the electronic chart. With respect to such a choice, the decisions and actions were based on the automatic positioning systems and navigation control. Thus, decisions about altering the speed and course of the ship were based on the automatically obtained data without checking them by the direct method of terrestrial or radar positioning of the objects on shore. Nautical chart was used to plot the coordinates from the GPS device, and on the basis of this information the course of leaving the anchorage was determined as well as the access to the traffic separation scheme, and eventually the course towards the port of Rotterdam. Within different groups there were no individual differences of opinion regarding the application of GPS as the primary means of ship positioning.

Unlike the previously mentioned groups, the third and the sixth group did not use automatic positioning to determine the course and speed of the ship. The method of terrestrial positioning by radar with two bearings was used for positioning on the nautical chart during leaving the anchorage, altering course and sailing in the traffic separation scheme. Thus, on the basis of the position obtained in this way, the decisions about altering course and speed of the ship were made. In both cases the position was compared with the electronic means of positioning, but only as an alternative source of information. However, the master of the third group explicitly required the use of radar as the primary means for positioning before the other crew members showed initiative in the choice of method for determining the position of the ship. With group six the second officer intended to use GPS positioning, but the master required radar positioning, and in the course of navigation the method of terrestrial radar positioning was consistently used.

The research clearly indicates the major phenomenon of technology indulgence which can be seen from the actions of the respondents in group one, two, four, five and seven.

Groups three and six did not surrender to the temptation of technology indulgence. However, the attempt by the second officer in group six to use GPS as the primary means of positioning is nevertheless significant, although the action was prevented by the master's intervention. In the third group the master was explicit regarding the selection of the method of ship's positioning.

This sequence of events points to another phenomenon that has not been directly studied. This phenomenon is uncritical leadership style, i.e. leadership indulgence. However, even here we can apply the elements of the socio-technical theory in terms of organization of human resources and work processes. According to Trist and Bamforth, the socio-technical theory pays special attention to leadership at group level and points to the team's responsible autonomy, while according to Rice smaller groups or teams are responsible for their internal organization and control based on individual initiative. In this sense, there has been a lack of teamwork. Looking at the overall operation of the crew in each group the presence of 
hierarchical authority of the master is notable. It is exactly the influence of the master in group three and six which was the decisive factor of crewmembers' actions. While from the aspect of technology indulgence we can talk about a positive influence, we should not ignore the possibility that in the master's absence the individuals can nevertheless act differently, as was the intention of the second officer in group six. However, since the aim of the research was to determine the objective attitudes of the respondents at management level, it was necessary to divide them into groups according to the same duties they perform in real life. Consequently, there is no doubt that the respondents as crewmembers onboard real ships would act in accordance with the results of the investigation.

Thus, five of the seven groups of respondents acted under the influence of technology. Out of 28 respondents 20 of them from group one, two, four, five and seven plus one respondent from group six showed the tendency toward passivizing their active knowledge in favour of the technological solutions offered. This makes a total of 21 seafarers out of the total number of 28 , or $75 \%$ of respondents which proves significant indulgence in technological solutions at the expense of active knowledge and skills as shown in Table 1 and Figure 2.

Table 1 - Ratio of radar and automatic positioning

\begin{tabular}{|c|c|c||}
\hline Group & $\begin{array}{c}\text { Respondents } \\
\text { who chose } \\
\text { radar positioning }\end{array}$ & $\begin{array}{c}\text { Respondents } \\
\text { who chose } \\
\text { automatic positioning }\end{array}$ \\
\hline \hline 1 & & 4 \\
\hline 2 & 4 & 4 \\
\hline 3 & & 4 \\
\hline 4 & 3 & 4 \\
\hline 5 & & 1 \\
\hline 6 & 7 & 4 \\
\hline 7 & & 21 \\
\hline \hline$\sum$ & &
\end{tabular}

\section{COMPARATIVE ANALYSIS OF THE USE OF TECHNOLOGY SOLUTIONS AND HUMAN RESOURCES FROM SOCIO-TECHNICAL ASPECT}

Control systems, especially manual controls, are based on four basic socio-technical elements: usability adapted to human, conversion of information, storing of information and management. All these elements can be improved by mechanical and / or electronic means.

Normally, we talk about three levels of control: compensatory, open and feedback (Figure 3). At the

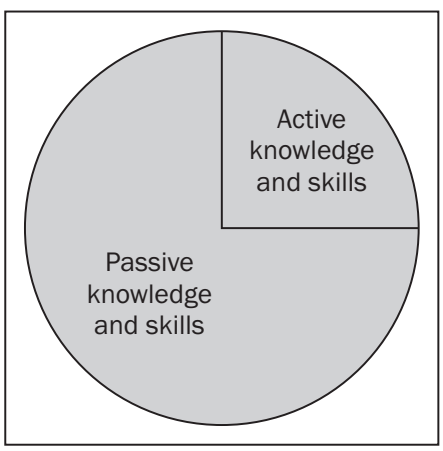

Figure 2 - Ratio of active and passive knowledge

compensation level the difference between the actual and the desired state of the value controlled is limited. Control performance at this level does not contain information from which the operator could make a comparison of actual and desired state. Open control is oriented towards identifying the desired control actions, and their programming. Control of feedback allows that on the basis of the data input the operator can predict the output data.

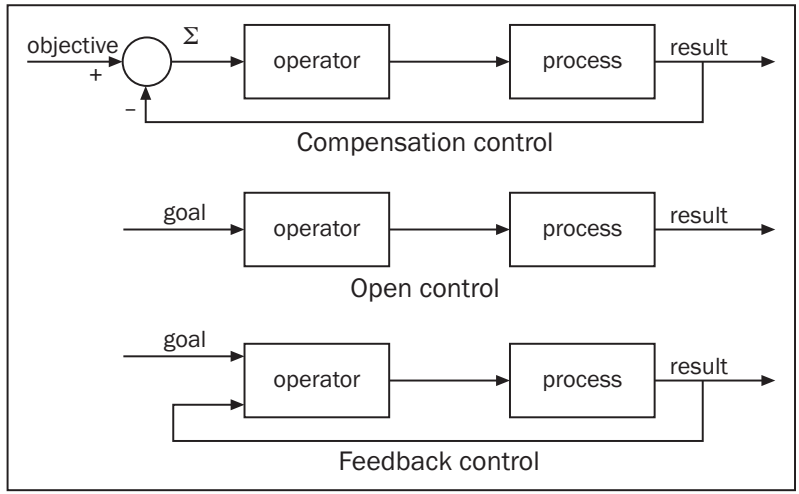

Figure 3 - Control systems

Source: Schuffel, H., Some Aspects of the Future Role of Ergonomics in Ship Control, 1981, p. 9

The possibility to notice or assume information on the goal differs from the possibility of controlling the process dynamics. In other words, this means that at the compensatory level of control the only useful information available as an actual result of the process is a deviation which can be minimized in relation to the goal. With the open control, information is used to initiate pre-programme control level after which the sequence of processes takes place irrespective of the result, i.e. the goal required.

Feedback control can be viewed at the level of the previous two combined. Taking into account the input information in relation to the desired result, the operator can predict when the result will become visible, and can draw conclusions about the progress on the basis of the process parameters such as speed or previously remembered information about the movement. Process values obtained at the output act as a function 
of input process values. The ability to predict output values of the process is a function of human knowledge, and it is also an active way of controlling the actual process parameters. From the socio-technical point of view the application of feedback control alone can satisfy the first socio-technical principle because it provides an opportunity for synchronized action in the human-technical system relationship.

Along with the development of engine automation there has been a development of automation on the navigating bridge where, for example, helmsman has been retained for safety reasons, tradition and unreliability of the instruments. Taking into account the development of automation on the bridge and in the engine room a comparison can be made of the levels at which automation took over some human functions of active control and work (usability, conversion, storage, management). The comparison will be presented at three levels of control: compensatory, open and feedback.

\begin{tabular}{|c|c|c|c|c|}
\hline \multicolumn{5}{|c|}{ Engine Room } \\
\hline $\begin{array}{l}\text { Level Elements of } \\
\text { of control }\end{array}$ & $\begin{array}{l}\text { Usability } \\
\text { adapted } \\
\text { to man }\end{array}$ & $\begin{array}{l}\text { Conversion } \\
\text { of infor- } \\
\text { mation }\end{array}$ & $\begin{array}{l}\text { Storage } \\
\text { of infor- } \\
\text { mation }\end{array}$ & $\begin{array}{l}\text { Manage- } \\
\text { ment }\end{array}$ \\
\hline Compensatory & A & $\mathrm{M}$ & $A$ & A \\
\hline Open & A & $\mathrm{M}$ & $A$ & A \\
\hline Feeback & $\mathrm{A}$ & $\mathrm{A}$ & $\mathrm{A}$ & A \\
\hline \multicolumn{5}{|c|}{ Bridge } \\
\hline Compensatory & $\mathrm{M}$ & $\mathrm{M}$ & $\mathrm{M}$ & $\mathrm{M}$ \\
\hline Open & A & $\mathrm{M}$ & $\mathrm{M}$ & $\bar{M}$ \\
\hline Feeback & $\mathrm{A}$ & $\mathrm{M}$ & $\mathrm{M}$ & $\mathrm{M}$ \\
\hline
\end{tabular}

Figure 4 - Level of automation in the engine room and on the bridge

Source: Schuffel, H., Some Aspects of the Future Role of Ergonomics in Ship Control, 1981, p.10

Figure 4 shows that engineers tend to have control function while deck officers, besides control function, also have the executive function. In this regard it is the diversity within control elements such as usability, data storage and management that strikes the eye. Data storage and management are discussed as automated control elements as far as engine is concerned, but not as regards the bridge where there is the alternative of manual controls and feedback control. Previous experience with automated ship control systems point to the first socio-technical principle of mismatch because of fatigue during the prolonged repetition of routine control activities. This occurs because of an excessive number of automated control elements at the compensatory level on the bridge and in the engine room that passivizes and sometimes confuses the operator by extensive and vague instructions - Integrated navigation systems, ARPA radar, electronic chart, GMDSS equipment, and automatic processes of engine control in the engine room.

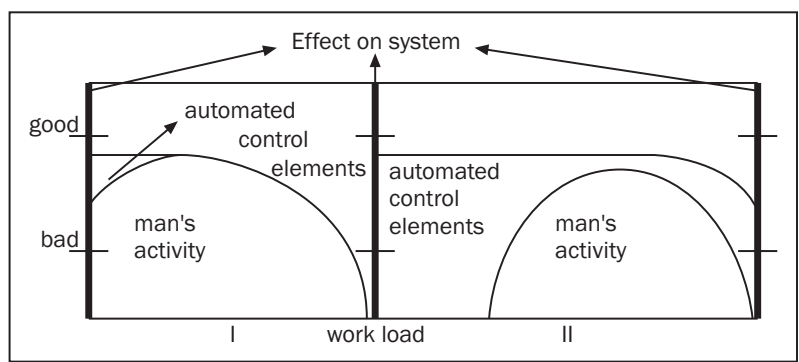

Figure 5 - Effect of human activities and automated control elements on the system

Source: Schuffel, H., Some Aspects of the Future Role of Ergonomics in Ship Control, 1981, p. 12

Figure 5 represents a qualitative comparison of automated systems (II) and the systems controlled mostly manually (I). Although system II has room for larger workloads, its efficiency is not greater than that of system I because of fatigue and lack of concentration, which are manifested when the human is in the role of passive process controller.

Technological possibilities of automation of processes are used as a way of reducing the need for human labour. Thus, savings are achieved by reducing the number of crew members. This directly implies the second socio-technical principle of domination, or accelerated development of the technical aspect which does not comply with the organizational elements and human resources. On the other hand, technology has allowed faster exploitation of the ship with regard to reducing the time needed for loading and discharging of cargo. At the same time, transport capacity of ships and average speed of navigation are increasing. Thus, by reducing the number of crew members the focus shifts to the domain of passive control and increased workload due to the faster ship exploitation and reduced number of crewmembers. Dynamic exploitation of the ship uses the space for higher workloads - System II. The result is fatigue in the field of applied automation and fatigue in the field of workload required to conduct the ship under way which is in contrast with the first socio-technical principle of human-technology synchrony. An alternative to changing over from automated to manual control is an option that is rarely used and also leads to passivizing operator which is expressed precisely at moments when there is the need of urgent and priority action. Such bases give rise to the phenomenon of technology indulgence, or the impact of technology on the move of active knowledge and skills to the area of passive ones and, ultimately, those that prove inaccessible in emergency situations. This thesis has been confirmed by Schuffel in the following conclusion: "Long-term performance of passive control operations reduces the need for traditional knowledge and skills resulting in a possible loss of such knowledge and skills." (1981:11). 
In relation to the second socio-technical principle only the elements of control at the feedback level justify the application of automation particularly to the processes that assist and support the operator. In this sense Rothblum (2000:8) ${ }^{7}$ suggests: "Human error can be significantly reduced by appropriate design of devices (equipment), work environment and an appropriate organization within which the equipment and work environment are designed with the basic assumption to support the operator and adapt to their abilities and constraints - human-centred design." At the same time, the observed passivization of human onboard ship requires his permanent training on the same kind of simulation devices on shore on which all foreseeable circumstances that may befall him should be trained. The imperative to create common standards of use for certain segments of equipment and devices is suggested by itself. In addition to the skills obtained through simulation technology the officers should continuously improve their current knowledge about the devices they operate. A study conducted on 100 maritime accidents that occurred between 1982 and 1985 indicate insufficient knowledge in the field of usage of devices and equipment that caused 35\% of accidents considered (Wagenaar, 1987:594).

\section{CONCLUSION}

Based on these considerations and research the non-compliance of the existing ship organization and technology has been observed. According to sociotechnical principles the non-compliance can be simultaneously viewed as a mismatch of human and technical resources, and a schematic diagram of a possible parallel management of socio-technical system is proposed as a scheme of optimizing the ship organization. In addition, it was found that the ship's organization still tends towards autocratic management which is the organizational throwback inherited from the traditional hierarchical structure of ship management. In this sense, the socio-technical theory supports the elements of teamwork at the group level and the principle of responsible autonomy of the team. The investigation conducted showed that $75 \%$ of respondents indulge to technical solutions and suppress active personal knowledge and skills. This leads to passivity of seamen's current knowledge and creativity, or decrease in satisfaction with maritime profession. Consequently, this brings about an increase in human error as the backbone of recent maritime accidents. In order to reduce the socio-technical mismatch the control systems have been comparatively observed and it was found that only the systems with feedback control harmonize the human with the system. Furthermore, inconsistencies were found with regard to automated systems at the compensatory level, causing mental and physical fatigue to the operator. Based on the aforementioned, a new conceptual approach has been proposed to the design of equipment and work environment with the basic requirement of adaptation of technology to human abilities and limitations (humancentred design). Accordingly, the creation of common standards of usage of the equipment and devices on the bridge and in the engine room has been proposed. The standardized equipment would be optimal to train seafarers and consistently develop knowledge about the devices operated in practice.

\section{Dr. SC. TONI BIELIĆ}

E-mail: toni.bielic@pfst.hr

Sveučilište u Splitu, Pomorski fakultet

Zrinsko-frankopanska 38, 21000 Split, Hrvatska

Dr. sc. ROBERT MOHOVIĆ

E-mail:mohovic@pfri.hr

Dr. SC. RENATO IVČE

E-mail: ivce@pfri.hr

Sveučilište u Rijeci, Pomorski fakultet

Studentska 2, 51000 Rijeka, Hrvatska

\section{SAŽETAK}

\section{SOCIOTEHNIČKI MODEL UČINKOVITOSTI ORGANIZACIJE BRODA}

Članak istražuje mogućnosti optimalizacije organizacije broda kao visoko kompleksnog tehničkog sustava. U tom smislu razmatra se postojeći odnos tehnologije i čovjeka kao korisnika. Sociotehničkim pristupom nastoje se identificirati slabe točke u postojećem tehnološko-organizacijskom sustavu broda. Na osnovi provedenih istraživanja na navigacijskom simulatoru uočene su sociotehničke komponente koje ugrožavaju sigurnost plovidbe. Naknadnim komparativnim analizama korištenja tehničkih rješenja sukladno potrebama čovjeka predložena su određena rješenja i zaključci.

\section{KLUUČNE RIJEČI}

sociotehnički model, brodska organizacija, sigurnost, učinkovitost, tehnološka podložnost, kontrolni sustavi, automatizacija

\section{REFERENCES}

1. Trist, E., Bamforth, K., Some social and psychological consequences of the longwall method of coal getting. In: Human Relations, 4, 1951, pp.3-38

2. Rice, A. Productivity and social organisation: The Ahmedabad experiment. London: Tavistock 1958

3. Wagenaar, W. A., Groeneweg, J., Accident at Sea: Multiple Causes and Impossible Consequences. International Journal of Man-Machine Studies, Volume 27, Issue 5-6 Nov/Dec 1987, pp. 587-598, Leiden University, Netherlands

4. Schuffel, H. Some Aspects of the Future Role of Ergonomics in Ship Control, Second Conference on Human Factors in the Design and Operations of Ships, 1981, Amsterdam 
5. Döring, B., Analytical Methods in Man-Machine System Development. In: Introduction to Human Engineering, Kraiss/Moraal-Verlag Tüv Rheinland Gmbh, Köln 1976

6. Bostrom, R.P., Heinen, J.S., MIS problems and failures: A socio-technical perspective, MIS Quaterly, Vol. 1, No. 3, 1977, pp. 17-32

7. Rothblum, A. Human Error and Marine Safety. Maritime Human Factors Conference, Linthicum 2000

\section{LITERATURE}

[1] Heller, F. Socio-technology and the Environment, Human Relations, Vol. 50, No 5, 1977, pp. 605-624
[2] Herrmann, T., Loser, K. Vagueness in models of sociotechnical systems. Behaviour \& Information Technology, 18(5), 1999, pp. 313-323

[3] Mumford, E., Designing human systems, the ETHICS approach. Manchester Business School, Manchester, U.K. 1983

[4] Trist, E., Murray, H., The Social Engagement of Social Science: A Tavistock Anthology (Vol. H), Philadelphia, University of Pennsylvania Press 1993

[5] Interactive Technologies and Socio-technical Systems, Proceedings of the $12^{\text {th }}$ International Conference, VSMM 2006, Xi`an, China, October 2006 